University of Nebraska - Lincoln

DigitalCommons@University of Nebraska - Lincoln

Papers in Biomaterials

Chemical and Biomolecular Engineering

Research and Publications

December 1992

\title{
Densities of Vegetable Oils and Fatty Acids
}

Hossein Noureddini

Department of Chemical Engineering, University of Nebraska-Lincoln, hnouredd@unlnotes.unl.edu

B C. Teoh

Department of Chemical Engineering, University of Nebraska-Lincoln

L Davis Clements

Department of Chemical Engineering, University of Nebraska-Lincoln

Follow this and additional works at: https://digitalcommons.unl.edu/chemeng_biomaterials

Part of the Biomaterials Commons

Noureddini, Hossein; Teoh, B C.; and Clements, L Davis, "Densities of Vegetable Oils and Fatty Acids" (1992). Papers in Biomaterials. 14.

https://digitalcommons.unl.edu/chemeng_biomaterials/14

This Article is brought to you for free and open access by the Chemical and Biomolecular Engineering Research and Publications at DigitalCommons@University of Nebraska - Lincoln. It has been accepted for inclusion in Papers in Biomaterials by an authorized administrator of DigitalCommons@University of Nebraska - Lincoln. 


\title{
Densities of Vegetable Oils and Fatty Acids
}

\author{
H. Noureddini ${ }^{*}, B . C$. Teoh and L. Davis Clements \\ Department of Chemical Engineering, University of Nebraska-Lincoin, Lincoln, Nebraska 68588-0126
}

Complete data for density as a function of temperature have been measured for a number of vegetable oils (crambe, rapeseed, corn, soybean, milkweed, coconut, lesquerella), as well as eight fatty acids in the range $\mathbb{C}_{9}$ to $\mathrm{C}_{22}$ at temperatures from above their melting points to $110^{\circ} \mathrm{C}\left(230^{\circ} \mathrm{F}\right)$. The specific gravity and density measurements were performed according to American Society for Testing and Materials (ASTM) standard test methods D 368, D 891 and D 1298 for hydrometers and a modified ASTM D 369 and D 891 for pycnometers. Correlation constants, based on the experimental data, are presented for calculating the density of fatty acids and vegetable oils in the range of temperature from $24^{\circ} \mathrm{C}\left(75^{\circ} \mathrm{F}\right)$ or the melting point of the substance, to $110^{\circ} \mathrm{C}\left(230^{\circ} \mathrm{F}\right)$. The constants are valuable for designing or evaluating such chemical process equipment as heat exchangers, reactors, process piping and storage tanks. Estimated density of fatty acids by a modified Rackett equation is also presented.

KEY WORDS: Density, fatty acids, specific gravity, vegetable oils.

Density or specific gravity data are important in numerous chemical engineering unit operations in the fatty acid industry. Representative examples include reactors for sphtting of fatty acids or conversion of fatty acids to their derivatives, distillation for separation of fatty acids, or for designing storage tanks and process piping. In addition, the pure component data for fatty acids may be used to ascertain mixture property values and to estimate oil density.

The data were measured by both hydrometer and pycnometer procedures in a single constant-temperature bath. Pycnometer measurements provide the true density of the material and the hydrometer measures specific gravity. Due to the tedious procedure involved in pycnometer measurements, they were used only for some of the data to validate the hydrometer readings over the entire range of temperature. This procedure resulted in a correction factor for hydrometer measurements. In all measurements the correction never exceeded $0.2 \%$.

\section{EXPERIMENTAL PROCEDURES}

A Precision Scientific (Chicago, IL) constant-temperature bath with a Micro-set Thermoregulator, in accordance with American Society for Testing and Materials (ASTM) D 445 (1), was used in the procedures for specific gravity and density determinations. This assembly maintains a temperature uniformity of $\pm 0.0033^{\circ} \mathrm{C}\left( \pm .005^{\circ} \mathrm{F}\right)$ throughout the range of 20 to $130^{\circ} \mathrm{C}\left(68\right.$ to $\left.266^{\circ} \mathrm{F}\right)$, exceeding the ASTM D 445 (1) requirements. Fisher's Precision Specific Gravity Hydrometers (Fisher Scientific, Pittsburgh, PA), ASTM D 1298 (2) with subdivisions of 0.001 , and Fisher thermometers, ASTM D 445 (1), with subdivisions of $0.056^{\circ} \mathrm{C}\left(0.1^{\circ} \mathrm{F}\right)$, were used for specific gravity and temperature readings, respectively.

*To whom correspondence should be addressed at Department of Chemical Engineering, 236 Avery Laboratory, University of Nebraska-Lincoln, Lincoln, NE 68588-0126.
A glass cylinder was installed through one of the holes in the bath cover assembly. The sample was placed inside the glass cylinder for hydrometer measurements. The bath temperature was set at the desired temperature and was monitored with a glass thermometer during the experiment. The temperature of the sample inside the glass cylinder was monitored with a second thermometer. At higher temperatures, where a temperature gradient may exist, the bath temperature was increased to maintain the desired temperature inside the cylinder. The specific gravities were determined according to the procedures in ASTM methods D 1298, D 368, and D 891 (2-4).

The pycnometer measurements were performed along with the hydrometer procedures in the same bath. Three 10-mL Fisher pycnometers, in accordance with ASTM D 369 (5), were used in all measurements. Pycnometers were filled with the sample at a temperature below the bath temperature. Heat resistant tubing was slipped over the outside of the pycnometer neck to prevent direct contact between the bath fluid and the capillary opening of the bottle. Figure 1 shows the pycnometer assembly. This assembly was secured to the bath cover and clip and

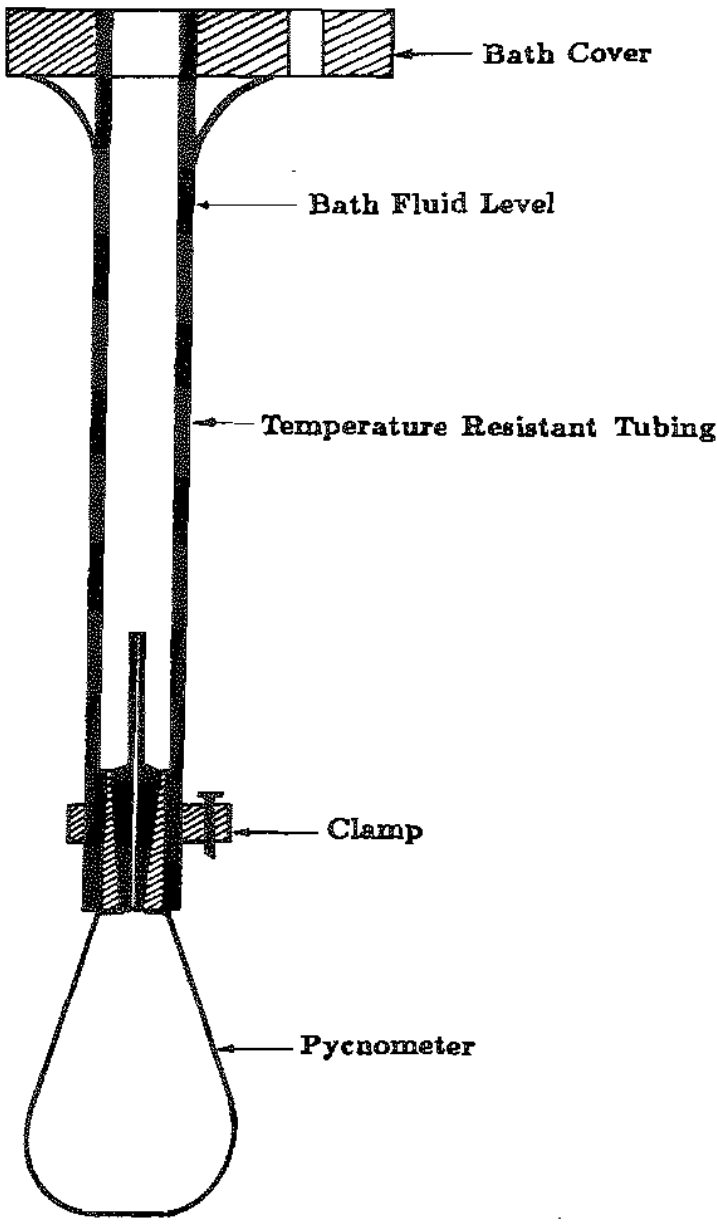

FIG. 1. Pycnometer assembly. 
DENSITIES OF VEGETABLE OILS AND FATTY ACIDS

TABLE 1

Fatty Acid Distributions and Sources of Vegetable Oils

\begin{tabular}{|c|c|c|c|c|}
\hline \multirow{2}{*}{$\begin{array}{l}\text { Vegetable } \\
\text { oils }\end{array}$} & \multicolumn{3}{|c|}{$\%$ Composition $^{a}$} & \multirow[b]{2}{*}{ Source or manufacturer } \\
\hline & Saturated & Monounsaturated & Polyunsaturated & \\
\hline Crambe $b$ & 5 & 79 & 16 & Texas A\&M University, College Station, TX \\
\hline Corn & 4.3 & 21.4 & 64.3 & Hain Pure Food Co. Inc., Los Angeles, CA \\
\hline Soybean & 14.3 & 28.0 & 57.1 & Hain Pure Food Co. Inc., Los Angeles, CA \\
\hline Milkweed & $\mathrm{NA}^{\mathrm{c}}$ & NA & NA & Biological System Eng., U. of Nebraska, Lincoln, NE \\
\hline Coconut & 94.0 & 5.0 & 1.0 & Vinton Pop Corn Co., Vinton, IA \\
\hline
\end{tabular}

$a$ Provided by the manufacturers. ${ }^{b}$ Approximate values. ${ }^{c}$ Not availabIe.

TABLE 2

Purity of Fatty Acids

\begin{tabular}{lcl}
\hline Acids & $\%$ Purity & \multicolumn{1}{c}{ Manufacturer } \\
\hline Nonanoic & 98 & Kodak, Rochester, NY \\
Capric & $99-100$ & Sigma, St. Louis, MO \\
Lauric & $99-100$ & Sigma \\
Myristic & 99 & Kodak \\
Palmitic & 99 & Sigma \\
Stearic & 95 & Aldrich, Milwaukee, WI \\
Oleic & 98 & J.T. Baker, Phillipsburg, PA \\
Erucic & 90 & Sigma \\
\hline
\end{tabular}

aprovided by the manufacturers.

immersed inside the bath. Except for the modifications for the pycnometer assembly, the procedures in the ASTM standard test methods D 891 and D $369(4,5)$ were followed for the density determinations.

The fatty acid composition and source or manufacturer of each vegetable oil are shown in Table 1 . Table 2 shows the purity and the manufacturers of the fatty acids used. The information on the fatty acid composition of vegetable oils and purity of the fatty acids were provided by the manufacturers.

\section{RESULTS}

The scale readings for the hydrometer were corrected for the glass expansion by using a glass expansion coefficient of $25 \times 10^{-6}$ per ${ }^{\circ} \mathrm{C}$. The specific gravity data for crambe and milkweed seed oils and for oleic acid were measured with both hydrometers and pycnometers. The hydrometer scale readings were corrected according to the pycnometer measurements. The correction was equal to 0.0025 . This correction was uniform and did not depend on temperature or type of oil or acid used. This correction was then applied to the rest of the samples, for which only the hydrometer measurements were performed. Densities were calculated by multiplying the specific gravities by water density $(0.99904 \mathrm{~g} / \mathrm{mL})$ at $15.5^{\circ} \mathrm{C}\left(60.0^{\circ} \mathrm{F}\right)$. This is the calibration temperature of the hydrometers. The results are tabulated in Tables 3 and 4. Available iterature values $(6,7)$ at $25^{\circ} \mathrm{C}\left(77^{\circ} \mathrm{F}\right)$ are presented for comparison.

A linear correlation was fitted to the experimental data. The linear coefficients are tabulated in Tables 5 and 6 . The percent mean deviations from experimental measure- ments are also included As expected, the deviations found were small. The mean deviation was less than $0.07 \%$ for all data. Figures 2 and 3 show the experimental and linear predictions for vegetable oils (lesquerella, milkweed, crambe) and for saturated fatty acids (nonanoic, capric, lauric, myristic, palmitic, stearic), respectively. Lines show the linear correlations compared to the experimental points.

The difference between successive test results by the same apparatus under constant operating conditions on identical test material never exceeded 0.0005 for hydrometer scale readings and 0.003 for pycnometer measurements. These are within the sensitivity limits imposed by ASTM test methods D 1298 and D $369(2,5)$, respectively. Random examination of results for other samples, for which hydrometer measurements were principally performed, confirmed the correction applied to the scale readings. Corrected data were also within the repeatability specifications given by the ASTM methods, thus justifying the application of the correction factor for the hydrometer measurements.

The modified Rackett equation (8) also can be used for calculation of fatty acid and vegetable oil densities. This approach can be used directly in most computer-aidedprocess-design programs such as PRO/IITM, DESIGN II $^{\mathrm{TM}}$ or HySim ${ }^{\mathrm{TM}}$. The modified Rackett equation requires the critical properties and an empirical parameter, $\mathrm{Z}_{\mathrm{RA}}$, for each acid as the basis for computing density as a function of temperature. The required critical properties and Rackett parameters are usually available in the component library or may be easily incorporated into the prograrn data file. The modified Rackett equation is as follows:

$$
e=\frac{M W}{\frac{R T_{c}}{P_{c}} Z_{R A}^{\left[1+\left(1-T_{r}\right)^{2 / 7}\right]}}
$$

$T_{c}$ and $P_{c}$ are the critical temperature and pressure, respectively; $Q$ is the density; $T_{t}$ is the reduced temperature $\left(\mathrm{T}_{\mathrm{r}}=\mathrm{T} Y \mathrm{~T}_{\mathrm{c}}\right) ; \mathrm{R}$ is the universal gas constant; $\mathrm{MW}$ is the molecular weight; and $\mathrm{Z}_{\mathrm{RA}}$ is the Rackett parameter, a correlating parameter unique to each compound. Critical properties for the fatty acids mentioned in this work are shown in Table 7. A more complete listing of fatty acid critical properties was found in earlier works (Halvorsen, J.D., W.C. Mammel, Jr. and L. Davis Clements, unpublished data). 


\section{TABLE 3}

Density of Vegetable Oils

\begin{tabular}{|c|c|c|c|c|c|c|c|}
\hline \multirow{2}{*}{$\begin{array}{l}\text { Temperature } \\
{ }^{\circ} \mathrm{C}\left({ }^{\circ} \mathrm{F}\right)\end{array}$} & \multicolumn{7}{|c|}{ Density $(\mathrm{g} / \mathrm{mL})$} \\
\hline & Crambe & Rapeseed & Corn & Soybean & Milkweed $^{a}$ & Coconut & Lesquerefla \\
\hline $23.9 \quad(75.0)$ & 0.9078 & 0.9073 & 0.9188 & 0.9193 & 0.9203 & & 0.9398 \\
\hline $48.9(120.0)$ & 0.8898 & 0.8908 & 0.9028 & 0.9023 & 0.9018 & 0.9033 & 0.9229 \\
\hline $60.0(140.0)$ & 0.8829 & 0.8839 & 0.8939 & 0.8939 & 0.8934 & 0.8949 & 0.9152 \\
\hline $82.2(180.0)$ & 0.8681 & 0.8686 & 0.8800 & 0.8795 & 0.8790 & 0.8795 & 0.8999 \\
\hline $100.0(212.0)$ & 0.8564 & 0.8579 & 0.8679 & 0.8674 & 0.8684 & 0.8669 & 0.8879 \\
\hline Literature data & & $0.903-0.907$ & $0.912-0.917$ & $0.914-0.918$ & & $0.916-0.918$ & \\
\hline Temp. $\left({ }^{\circ} \mathrm{C}\right)^{b}$ & & 25 & 25 & 25 & & 25 & \\
\hline
\end{tabular}

$a_{\mathrm{By}}$ direct pycnometer determination. Other values by corrected hydrometer determination. ${ }^{b}$ Ref. 6 .

\section{TABLE 4}

Density of Fatty Acids

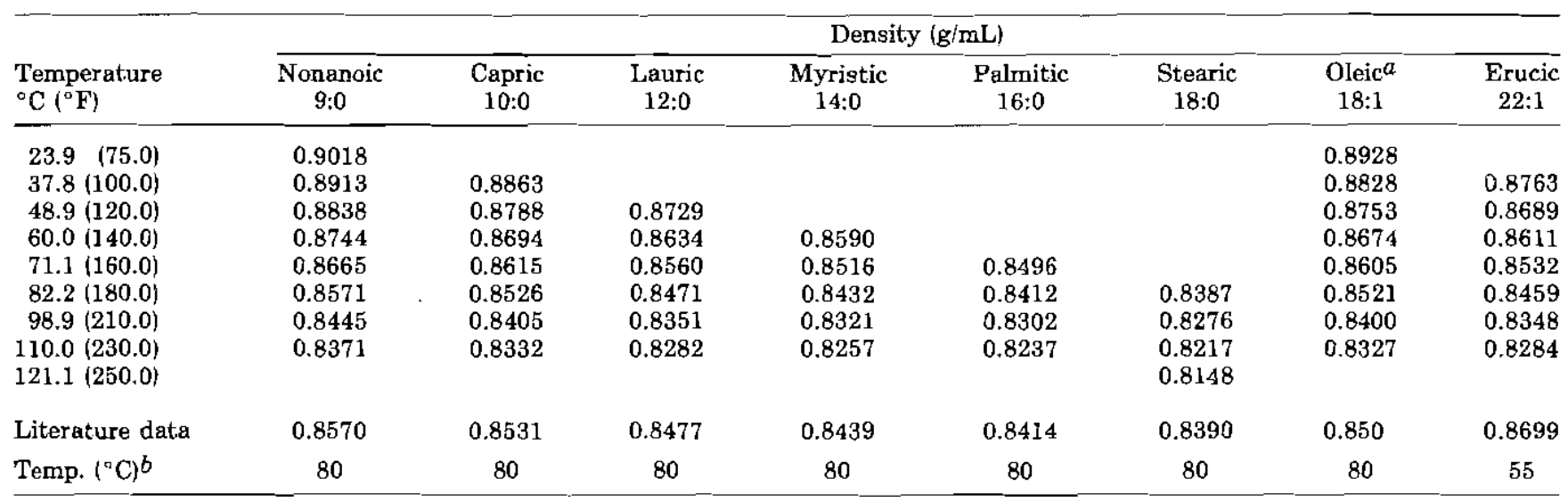

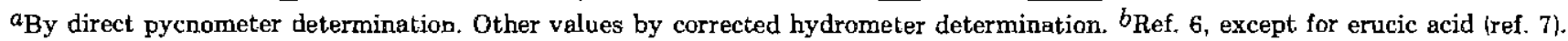

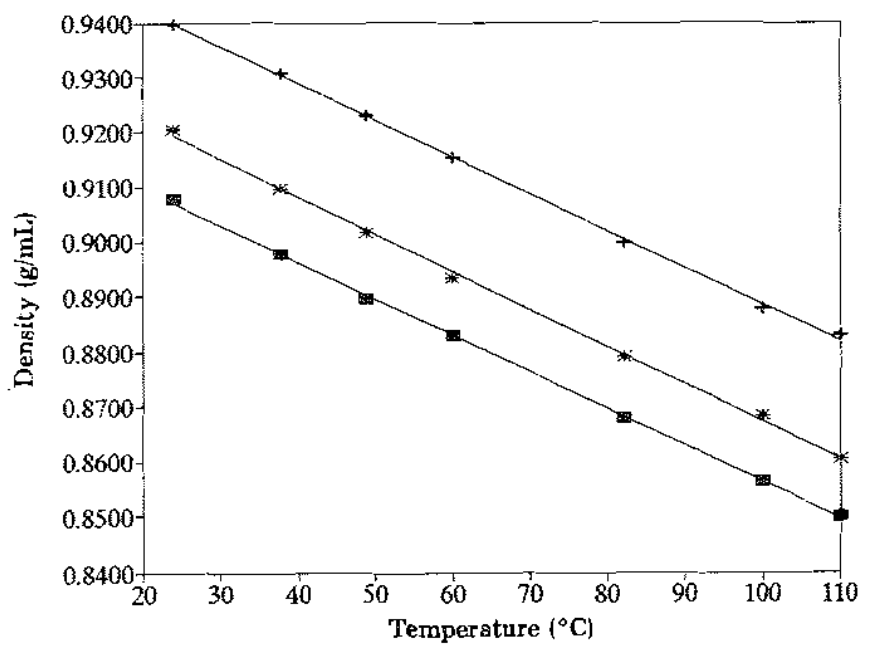

FIG. 2. Density os temperature for vegetable oils. The hines are correlation derivatives and the points are experimentaI data. (+), Lesquerella; ("), milkweed; and (韵), crambe.

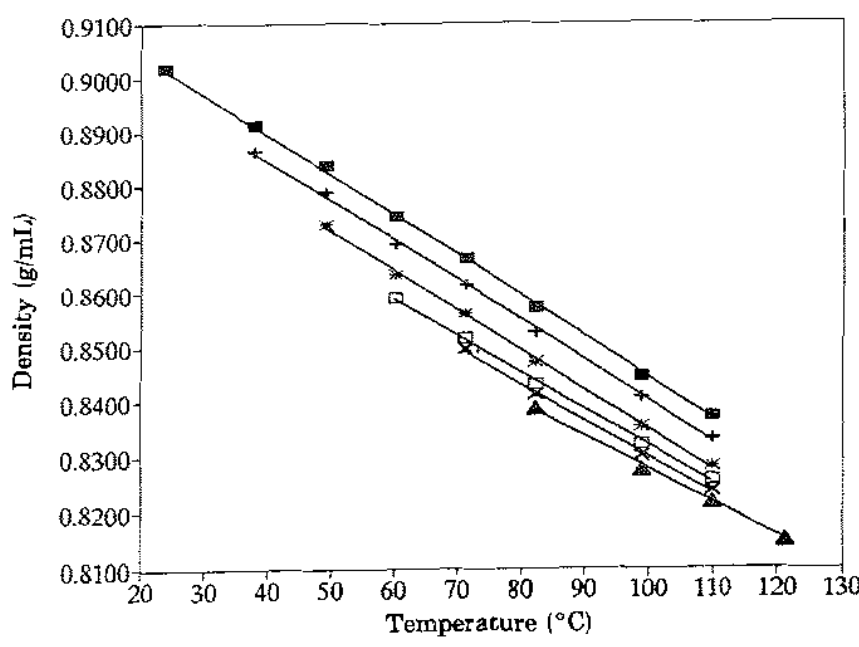

FIG. 3. Density vs. temperature for fatty acids. The lines are correlation derivatives and the points are experimentel data. (圆), Nonanoic acid; $(+)$, capric acid; $\left({ }^{*}\right)$, lauric acid; (D), myristic acid; $(X)$, palmitic acid; and (A), stearic acid. 
TABLE 5

Linear Correlations ${ }^{\complement}$ for the Vegetable Oil Densities $(\mathrm{g} / \mathrm{mL}$ )

\begin{tabular}{|c|c|c|c|c|c|}
\hline \multirow{2}{*}{$\begin{array}{l}\text { Vegetable } \\
\text { oils }\end{array}$} & \multicolumn{2}{|c|}{ Constants } & \multirow{2}{*}{$\begin{array}{c}\text { Data points } \\
n\end{array}$} & \multirow{2}{*}{$\begin{array}{c}\% \text { Mean deviation } \\
\mathbf{r}\end{array}$} & \multirow{2}{*}{$\begin{array}{c}\text { Temperature range } \\
\left.\qquad{ }^{\circ} \mathrm{C}\right)\end{array}$} \\
\hline & $m$ & c & & & \\
\hline Crambe & $-6.665 F_{i}-04$ & $9.2300 \mathrm{E}-01$ & 7 & 0.032 & $23.9-\mathrm{I} 10.0$ \\
\hline Rapeseed & $-6.550 \mathrm{E}-04$ & $9.2305 \mathrm{E}-01$ & 7 & 0.029 & $23.9-110.0$ \\
\hline Corn & $-6.650 \mathrm{E}-04$ & $9.3432 \mathrm{E}-01$ & 7 & 0.056 & $23.9-110.0$ \\
\hline Soybean & $-6.674 \mathbf{E}-04$ & $9.3441 \mathrm{E}-01$ & 7 & 0.057 & $23.9-110.0$ \\
\hline Milkweed & $-6.820 \mathrm{E}-04$ & $9.3552 \mathrm{E}-01$ & 7 & 0.069 & $23.9-110.0$ \\
\hline Coconut & $-7.000 \mathrm{E}-04$ & 9.3716E-01 & 6 & 0.026 & $37.8-110.0$ \\
\hline Lesquerella & $-6.709 \mathrm{E}-04$ & $9.5569 \mathrm{E}-01$ & 7 & 0.049 & $23.9-110.0$ \\
\hline
\end{tabular}

$a_{\text {Density }}=\mathrm{c}+\mathrm{mT}$.

\section{TABLE 6}

Linear Correlations ${ }^{a}$ for the Fatty Acid Densities (g/mL)

\begin{tabular}{|c|c|c|c|c|c|c|}
\hline \multirow{2}{*}{$\begin{array}{l}\text { Fatty } \\
\text { acids }\end{array}$} & \multirow[b]{2}{*}{ Carbon } & \multicolumn{2}{|c|}{ Constants } & \multirow{2}{*}{$\begin{array}{c}\text { Data points } \\
\mathbf{n}\end{array}$} & \multirow{2}{*}{$\begin{array}{c}\% \text { Mean deviation } \\
r\end{array}$} & \multirow{2}{*}{$\begin{array}{l}\text { Temperature range } \\
\left(1^{\circ} \mathrm{C}\right]\end{array}$} \\
\hline & & $\mathrm{m}$ & $\mathrm{c}$ & & & \\
\hline Nonanoic & $9: 0$ & $-7.595 \mathrm{E}-04$ & $9.2015 \mathrm{E}-01$ & 8 & 0.048 & $23.9-110.0$ \\
\hline Capric & $10: 0$ & $-7.453 \mathrm{E}-04$ & $9.1452 \mathrm{E}-01$ & 7 & 0.047 & $37.8-110.0$ \\
\hline Lauric & $12: 0$ & $-7.319 \mathrm{E}-04$ & $9.0792 \mathrm{E}-01$ & 6 & 0.067 & $48.9-110.0$ \\
\hline Myristic & $14: 0$ & $-6.727 \mathrm{E}-04$ & $8.9909 \mathrm{E}-01$ & 5 & 0.055 & $60.0-110.0$ \\
\hline Palmitic & $16: 0$ & $-6.649 \mathrm{E}-04$ & $8.9634 \mathrm{E}-01$ & 4 & 0.060 & $71.1-110.0$ \\
\hline Stearic & $18: 0$ & $-6.081 E-04$ & $8.8838 E-01$ & 4 & 0.036 & $82.2-121.1$ \\
\hline Oleic & $18: 1$ & $-6.982 \mathrm{E}-04$ & $9.0946 \mathrm{E}-01$ & 8 & 0.023 & $23.9-110.0$ \\
\hline Erucic & $22: 1$ & $-6.694 \mathrm{E}-04$ & $9.0131 \mathrm{E}-01$ & 7 & 0.042 & $37.8-110.0$ \\
\hline
\end{tabular}

$u_{\text {Density }}=\mathrm{c}+\mathrm{mT}$.

TABLE 7

Fatty Acid Densities and Properties for Use with the Rackett Equation

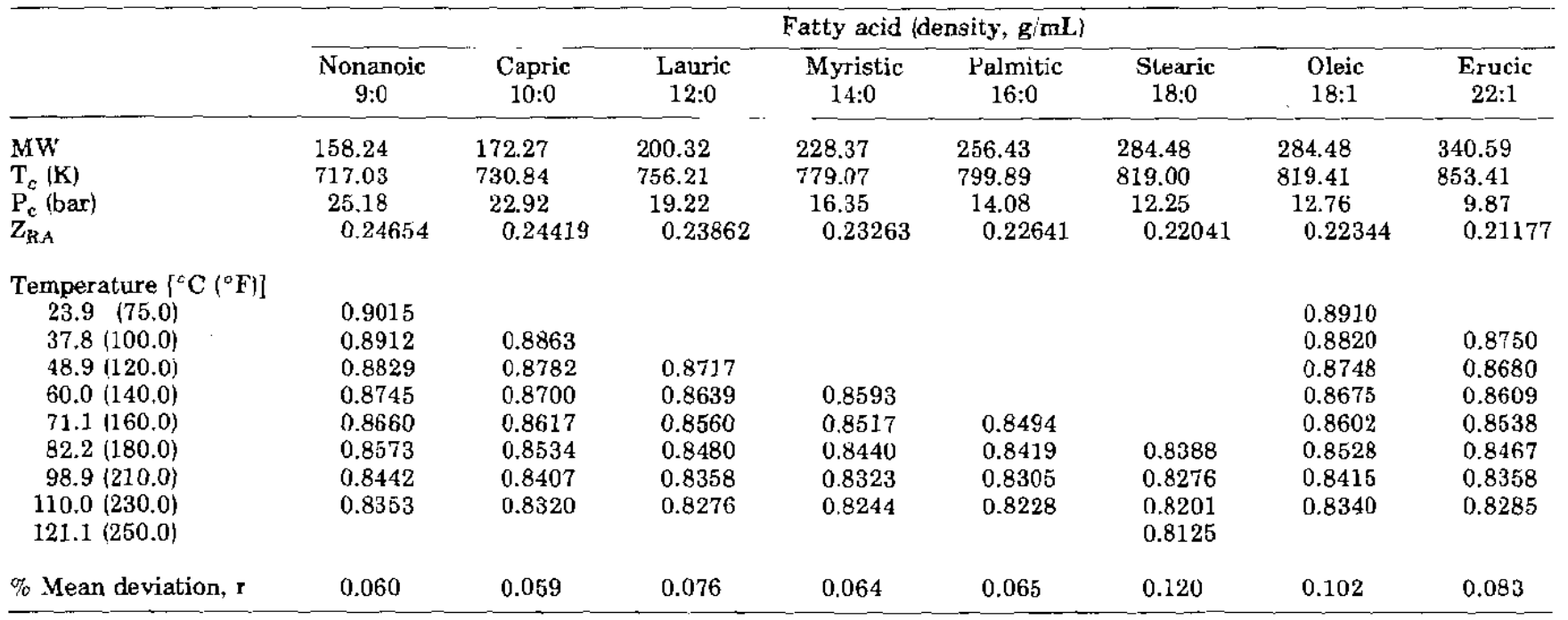




\section{H. NOUREDDINI ET AL.}

The modified Rackett equation predicts the liquid density with an average error of $0.08 \%$, which is of sufficient accuracy for use with process design calculations.

\section{ACKNOWLEDGMENT}

The authors express their gratitude to U. S. Department of Agriculture Cooperative State Research Service for its support of this work.

\section{REFERENCES}

1. Methods of the Americon Society for Testing and Materials, edited by Susan P. Canning, Paula C. Fazio, Donna Fisher, Elizabeth L. Gutman, Catherine T. Hsia, Sharon L. Kauffnan, Ioanne Kramer, Marianne Lane, Christine M. Leinweber and Patricia A. McGee, 1991, pp. 168-173, Method D 445.
2. Ibid, 1991, pp. 484-488. Method D 1298.

3. Ibid, 1991, pp 132-133, Method D 368.

4. Ibid, 1991, pp 1-4, Method D 891.

5. Ibid, 1991, pp. 134-136, Method D 369.

6. Forma, M.W., E. Jungermann, F.A. Norris and N.O. Sonntag, Bailey's Industrial Oil and Fat Products, edited by D. Swern, 4th edn, Vol. 1, John Wiley and Sons, New York, 1979, pp. 186-189.

7. Ullmann's Encyclopedia of Industrial Chemistry; edited by W. Gerhartz, Y.S. Yamamoto, L. Kaudy, J.F. Rounsaville and G. Schulz, 5th cdn, VoI. A10, 1985, p. 247.

8. Spencer, C.F. and R.P. Danner, J. Chem. and Eng. Data 17:236 (1972).

[Received May 1, 1992; accepted October 12, 1992] 